\title{
In vitro kinetic parameters of marandu palisadegrass associated with nonfiber carbohydrates
}

\section{Parâmetros cinéticos da digestão in vitro do capim marandu associado a carboidratos não fibrosos}

\author{
Perivaldo de Carvalho ${ }^{1 *}$; Luciano da Silva Cabral$^{2}$; Nelcino Francisco de Paula ${ }^{2}$; \\ Isis Scatolin de Oliveira²; Rodrigo Dias Lauritano Pacheco ${ }^{3}$; \\ Mariane Moreno Ferro ${ }^{4}$; Arthur Behling Neto ${ }^{2}$; Bruna Gomes Macedo \\ Isabela Eloisa Bianchi ${ }^{5}$; Karine Dalla Vecchia Camargo ${ }^{6}$
}

\begin{abstract}
This study aimed to evaluate the effects of different levels $(0,10,20$ and $30 \%)$ of starch or glucose associated with marandu palisadegrass (Urochloa brizantha cv. Marandu) on its kinetic parameters and fiber digestion by the in vitro gas production technique. The experiment was arranged in a completely randomized design, with four treatments and six replications for each energy source. The marandu palisadegrass associated with nonfiber carbohydrate levels was incubated in $120 \mathrm{ml}$ bottles, with McDougall buffer and rumen fluid from two rumen-cannulated sheep. Readings were taken of gas pressure within the bottle, and two vials were removed at 24, 48 and 96 hours (h) to assess residual neutral detergent fiber (NDF). The one-pool logistic model was used to estimate the kinetic parameters for pure forage and forage associated with starch, however it was necessary to use the two-pools model when glucose was added. Each $1 \%$ of added starch promoted a linear increase in total gas production of $0.2254 \mathrm{ml}$ and a decrease in lag time of $0.2451 \mathrm{~h}$, but did not affect the digestion rate. Glucose levels had a quadratic effect on digestion rate and lag time, with a minimum estimated value for digestion rate of $0.01689 \mathrm{~h}^{-1}$ at a glucose level of $10.07 \%$ and a minimum lag time of zero. Starch levels caused a linear reduction in NDF digestion of $0.296 \%$ only at $24 \mathrm{~h}$, while glucose levels linearly reduced the NDF digestion in all evaluated times $(0.3269,0.4171$ and $0.2340 \%$ at 24,48 and $96 \mathrm{~h}$, respectively). Glucose levels promoted different effects on the in vitro gas production kinetic parameters of marandu palisadegrass compared to starch supplementation, highlighting the prolonged negative effects on NDF digestion.
\end{abstract}

Key words: Digestion rates. Glucose. Neutral detergent fiber. Ruminants. Starch. Tropical forage.

\footnotetext{
${ }^{1}$ Discente de Doutorado em Agricultura Tropical, Universidade Federal de Mato Grosso, UFMT, Cuiabá, MT, Brasil. E-mail: perivaldo_carvalho@hotmail.com

2 Profs. Drs., UFMT, Cuiabá, MT, Brasil. E-mail: lucianoufmt@gmail.com; nelcinodepaula@hotmail.com; arthur_behling@ hotmail.com; isisscatolin@hotmail.com

${ }_{3}$ Pesquisador, Empresa Mato-Grossense de Pesquisa, Assistência e Extensão Rural, EMPAER, Cuiabá, MT, Brasil. E-mail: pachecozoo@yahoo.com.br

4 Discente de Doutorado em Ciência Animal, UFMT, Cuiabá, MT. E-mail: mmf zootecnia@yahoo.com.br

5 Discentes de Mestrado em Ciência Animal, UFMT, Cuiabá, MT. E-mail: bruna-macedoo@live.com; isabela_bianchi@outlook. com

${ }^{6}$ Discente de Graduação em Zootecnia, UFMT, Cuiabá, MT, Brasil. E-mail: karinedallavecchia@hotmail.com

* Author for correspondence
} 


\title{
Resumo
}

\begin{abstract}
Objetivou-se avaliar efeitos de níveis $(0,10,20$ e $30 \%)$ de amido ou glicose associado ao capim Urochloa brizantha cv. Marandu sobre os parâmetros cinéticos e digestão da fibra por meio da técnica in vitro de produção de gases. $\mathrm{O}$ experimento foi organizado em um delineamento inteiramente casualizado, com quatro tratamentos e 6 repetições para cada fonte energética. O capim Marandu associado aos níveis de carboidratos não fibrosos foi incubado em frascos de $120 \mathrm{~mL}$, com tampão de McDougall e inóculo ruminal proveniente de dois ovinos canulados no rúmen. Foram realizadas leituras da pressão dos gases no interior dos frascos, bem como dois frascos foram retirados nos tempos 24,48 e 96 horas (h) para avaliação da FDN residual. Utilizou-se modelo logístico com um compartimento para estimar os parâmetros cinéticos para a forragem ou da forragem associada a amido, entretanto foi necessário utilizar o modelo bicompartimental quando da adição de glicose. Cada $1 \%$ de amido adicionado promoveu aumento linear na produção total de gases em $0,2254 \mathrm{~mL}$ e redução do período de latência em 0,2451 h, mas não afetou a taxa de digestão. Já os níveis de glicose causaram efeito quadrático sobre a taxa de digestão e latência, sendo estimado valor mínimo da taxa de digestão de $0,01689 \mathrm{~h}^{-1}$ no nível de glicose de $10,07 \%$ e latência mínima igual a zero. Os níveis de amido causaram redução linear da digestão da FDN em 0,296\% apenas no tempo $24 \mathrm{~h}$, enquanto que os níveis de glicose reduziram linearmente a digestão da FDN em todos os tempos avaliados $(0,3269 ; 0,4171$ e $0,234 \%$, nos tempos 24, 48 e 96 h, respectivamente). Os níveis de glicose promovem efeitos diferenciados sobre os parâmetros cinéticos da produção de gás in vitro do capim Marandu comparado à suplementação com amido, destacando seus efeitos negativos prolongados sobre a digestão da FDN.
\end{abstract}

Palavras-chave: Amido. FDN. Forragem tropical. Glicose. Ruminantes. Taxas de digestão.

\section{Introduction}

Ruminant production in Brazil is mostly based on tropical forages, due to the ability of these animals to ingest and digest fibrous feed, as well as the country's climate conditions. Thus, these food sources provide the nutrient supply for most of the maintenance requirements of animal production (PAULINO et al., 2006). However, during the dry season as well as in more intensive grazing animal production systems, the forages may be supplemented with ingredients rich in nonfiber carbohydrates (NFC), which, while providing rapid fermentation energy to the rumen microflora, can have adverse effects on the ruminal ecosystem and fiber digestion (COSTA et al., 2009).

However, there is still controversy about the effects of these compounds in the rumen environment, especially regarding the microflora that digests fibrous carbohydrates. In general, it is assumed that low supplementation levels promote beneficial effects on forage NDF digestion, while high levels promote adverse effects. Whereas the goal of supplementation with NFC is to increase energy supply to the rumen microflora and the animal, thereby resulting in higher performance, it would not be desirable to decrease forage NDF digestion or develop negative effects on the kinetic parameters of its digestion by the rumen microflora (KRAUSE et al., 2003).

In grazing cattle supplementation strategies, a substitutive effect has been noted and linked to interactions between the supplemented NFC and forage, where an increase in NFC levels in the diet decreases digestion of the forage NDF. The theoretical basis for this effect is the competition for nutrients in the rumen environment between NFC fermenting microorganisms and those that digest fiber (ARROQUY et al., 2005), as there is a possible rumen $\mathrm{pH}$ drop due to the more rapid and extensive NFC digestion in the rumen, which inhibits the fibrolytic population at a $\mathrm{pH}$ below 6.0 (HADDAD; GRANT, 2000; GRANT; MERTENS, 1992).

Given the above, the goal was to evaluate the addition of energy sources (starch or glucose) to marandu palisadegrass (Urochloa brizantha cv. Marandu) on the in vitro gas production kinetic 
parameters and NDF digestion.

\section{Material and Methods}

The study was performed at the Laboratory of Animal Nutrition, at Federal University of Mato Grosso (UFMT), Cuiabá-MT campus. The evaluated forage was comprised of Urochloa brizantha cv. Marandu leaf blade samples, from a five year established pasture, fertilized with $90 \mathrm{~kg} \mathrm{ha}^{-1}$ of $\mathrm{N}$, with an average dry matter yield of $4,800 \mathrm{Kg} \mathrm{ha}^{-1}$. Forage was harvested by simulated grazing, at rainy season, 42 days after the uniformization cut, at the UFMT experimental farm located at Santo Antônio do Leverger-MT.

After drying under forced ventilation at $60{ }^{\circ} \mathrm{C}$ for $72 \mathrm{~h}$, the forage was ground with a $1 \mathrm{~mm}$ screen in a Wiley mill, and subsequently analyzed for dry matter (DM), organic matter (OM) crude protein (CP) and neutral detergent fiber (NDF) according to techniques described by Detmann et al. (2012). The composition of Urochloa brizantha cv. Marandu and supplements used in the in vitro experiment is presented in Table 1.

Table 1. Chemical composition of forage and supplements.

\begin{tabular}{|c|c|c|c|}
\hline \multirow[b]{2}{*}{ Item } & \multicolumn{3}{|c|}{ Component } \\
\hline & Forage & Starch & Glucose \\
\hline DM (dry matter $)^{1}$ & 230.0 & 1000 & 1000 \\
\hline $\mathrm{OM}(\text { organic matter) })^{2}$ & 930.0 & - & - \\
\hline $\mathrm{CP}(\text { crude protein })^{2}$ & 95.5 & - & - \\
\hline NDF (neutral detergent fiber) ${ }^{2}$ & 585.8 & - & - \\
\hline $\mathrm{Ash}^{2}$ & 70.0 & - & - \\
\hline
\end{tabular}

${ }^{1} \mathrm{~g} \mathrm{~kg}^{-1}$ of fresh matter; ${ }^{2} \mathrm{~g} \mathrm{~kg}^{-1}$ of dry matter.

To constitute the treatments, the forage was used as a reference point for addition of the other components, in order to simulate the situation of cattle grazing during the rainy season. The treatments consisted of replacing the forage with different percentages of glucose or starch energy sources. Specifically, the evaluated starch treatments were: 1) $100 \%$ forage, 2) $90 \%$ forage $+10 \%$ starch, 3) $80 \%$ forage $+20 \%$ starch, and 4) $70 \%$ forage $+30 \%$ starch. Likewise, the treatments with glucose were: 1) $100 \%$ forage, 2) $90 \%$ forage + $10 \%$ glucose, 3) $80 \%$ forage $+20 \%$ glucose, and 4 ) $70 \%$ forage $+30 \%$ glucose. The type of supplement used was based on the energy source purity and on the absence of NDF or protein, which allowed for exclusive evaluation of the forage insoluble fiber fraction degradation. The following sources were used: starch (soluble starch P.A. SYNTH) or glucose (D-glucose - ANHYDROUS P.A.).

Three successive incubations were performed in order to identify variations between incubations. For inoculation, rumen fluid from two castrated and rumen-cannulated sheep was used. The animals were kept in individual covered pens with concrete floors, equipped with individual feeders and water drinkers. For 30 days prior to ruminal liquid collection, the donor animals were adapted to a diet consisting of roughage plus concentrate in a proportion of 70:30, respectively. As roughage, the same forage that was incubated was used, and the concentrate was composed of soybean meal, corn and mineral mixture with 21\% CP (DM basis). The rumen fluid was obtained from the liquid:solid interface of the rumen environment, and was filtered by a triple layer of cheesecloth, immediately maintained in a thermal container and transported 
to the incubation room under anaerobic conditions.

Forage aliquots (amount according to treatment) were placed in glass flasks with a total volume of 120 $\mathrm{mL}$. Then the energy source was added according to the structure of the above described treatments, for a total of $500 \mathrm{mg}$ DM per flask for all treatments.

Subsequently, McDougall buffer solution (McDOUGALL, 1948) was added to the flasks. The solution had been previously adjusted to a $\mathrm{pH}$ of 6.8 by flushing with $\mathrm{CO}_{2}$ without oxygen. A freshly prepared reducing solution consisting of $625 \mathrm{mg} \mathrm{L}^{-1}$ $\mathrm{HCl}$-cysteine and $1000 \mathrm{mg} \mathrm{L}^{-1} \mathrm{Na}_{2} \mathrm{SO}_{3}$ was added to the buffer solution. In each flask, $40 \mathrm{~mL}$ of the total solution (buffer solution and reducing solution) was added 30 minutes before inoculation, while flushing with $\mathrm{CO}_{2}$ so that anaerobic conditions were ensured, while the flasks were kept in a water bath at $39^{\circ} \mathrm{C}$.

Next, $10 \mathrm{ml}$ of ruminal fluid was inoculated into each flask, always under $\mathrm{CO}_{2}$ flushing. The flasks were then immediately sealed with a rubber stopper and aluminum seal, and placed in a $39{ }^{\circ} \mathrm{C}$ water bath with an orbital agitation system (CABRAL et al., 2002). After the flasks were sealed, the gases present inside were released with a needle, and time was computed for gas pressure readings realization.

To correct the gas volume from the rumen fluid and the buffer solution, three flasks were incubated without sample (blank), thus, for each reading time, the gas volume of flasks with the sample was subtracted by the volume of flasks without samples.

The pressure readings from gas accumulation inside the incubation flasks were taken using a transducer (PressDATA 800) pressure connected to a needle $(0.7 \mathrm{~mm})$, at the following times: $1,2,3$, $4,5,6,7,8,9,10,11,12,14,16,18,20,22,24$, $30,36,42,48,60,72,84$ and $96 \mathrm{~h}$ after the start of incubation. The incubation procedure was repeated three times for a total of three evaluations for each incubation time for each treatment. Incubations were done in sequence. Six flasks were used for each treatment in each incubation, two of which were randomly taken and analyzed at 24,48 and $96 \mathrm{~h}$ for residual NDF, through autoclave use, to evaluate the possible effect of energy sources on NDF digestion (PELL; SCHOFIELD, 1993).

At the end of each incubation time mentioned above, flasks were removed from the water bath and subjected to $\mathrm{pH}$ measurement with a digital potentiometer, to which $50 \mathrm{ml}$ of neutral detergent solution was added (DETMANN et al., 2012). After being sealed again, flasks were autoclaved $\left(105^{\circ} \mathrm{C}\right.$ for one hour) in order to extract all components soluble in neutral detergent (PELL; SCHOFIELD, 1993). Then contents were filtered under vacuum in a glass filter crucible (porosity 2) and washed with hot distilled water and acetone PA. The NDF residue was obtained after the material was dried in non-ventilated oven $\left(105^{\circ} \mathrm{C}\right.$ for $\left.16 \mathrm{~h}\right)$.

The gas production data from incubation times were used for the construction of cumulative gas production profiles in an excel sheet, which were used to estimate the kinetic parameters of sample digestion through the model proposed by Schofield et al. (1994), using only one-pool for samples of pure forage or forage supplemented with starch (1) and two pools for treatments with glucose (2):

$\mathrm{Gas}=\mathrm{Vf} /(1+\exp (2-4 * \mathrm{c} *(\mathrm{t}-\mathrm{L})))$

Where Vf represents the gas final volume $(\mathrm{mL})$; $\mathrm{c}\left(\mathrm{h}^{-1}\right)$, the DM digestion rate; $\mathrm{t}(\mathrm{h})$, the incubation time; and L (h), the lag time.

Gas $=\mathrm{Vfa} /(1+\exp (2-4 * \mathrm{c} 1 *(\mathrm{t}-\mathrm{L})))+$

$\mathrm{Vfb} /(1+\exp (2-4 * \mathrm{c} 2 *(\mathrm{t}-\mathrm{L})))$;

Where Vfa represents the maximum estimated gas volume $(\mathrm{mL})$ for the rapid digestion fraction; $\mathrm{Vfb}$, the maximum estimated gas volume $(\mathrm{mL})$ for the slow digestion fraction; $\mathrm{cl}\left(\mathrm{h}^{-1}\right)$, the estimated digestion rate for the rapid digestion fraction; c2 $\left(\mathrm{h}^{-1}\right)$, the estimated digestion rate for the slow digestion fraction; $\mathrm{t}$, the incubation time $(\mathrm{h})$; the gas production at time $(\mathrm{t})$ equals the sum of $\mathrm{Vfa}+\mathrm{Vfb}$; and $L(h)$, represents the duration of initial events of ruminal digestion, common to the two digestion stages. 
The use of the one or two-pools models was based on the gas production profiles as well as the $\mathrm{R}^{2}$ values obtained, and the biological meaning of the estimated parameters (digestion rates and lag time). Thus, the one-pool model was not suitable for glucose as it affected the cited items, requiring the use of the two-pools model.

The estimated kinetic parameters and NDF digestibility were analyzed in a completely randomized design using the PROC MIXED of SAS (version 9.3). The statistical model was as follows:

$$
Y_{i j}=\mu+T_{i}+\varepsilon_{i j}
$$

Where $\mathrm{Y}_{\mathrm{ij}}$ is the dependent variable, $\mu$ is the general mean, $\mathrm{T}_{\mathrm{i}}$ is the starch or glucose level effect, and $\mathrm{E}_{\mathrm{ij}}$ is the residual error.

Starch and glucose levels were considered as fixed effects, and incubations as random effects. Before statistical analysis, the means were obtained for each incubation, which was used as the experimental unit (UDÉN et al., 2012). The LSMEANS option was used to obtain individual means for each treatment. Orthogonal polynomials were used to specifically partition the starch and glucose level effects in linear, quadratic and cubic order. In all analyses, significance was set at 5\%.

\section{Results and Discussion}

The $\mathrm{R}^{2}$ values for how the model fits the data were high, as the lowest value was 0.98 , which suggests that the one-pool model was adequate for estimating the kinetic parameters of forage digestion with or without starch inclusion.

There was no effect of starch level on forage digestion rate $(\mathrm{C})$, as an average value of 0.0218 $\mathrm{h}^{-1}$ was observed (Table 2), similar to that reported by Detmann et al. (2011) for low quality forage digestion rate $\left(0.0227 \mathrm{~h}^{-1}\right)$. This may be due to the good quality of the forage used as well as the efficient buffering provided by the McDougall buffer, since the final $\mathrm{pH}$ values were not affected $(\mathrm{pH}=6.76)$ by starch levels. According to Mertens and Loften (1980), when medium $\mathrm{pH}$ is reduced to values below 6.0, fiber digestion can be reduced, which was not verified in this study.

Table 2. Gas final volume (VF), dry matter digestion rate (C) and lag time (L) when starch was used to replace forage.

\begin{tabular}{|c|c|c|c|c|c|c|c|c|}
\hline \multirow{2}{*}{ Parameters } & \multicolumn{4}{|c|}{ Starch levels (\%) } & \multirow{2}{*}{ SEM } & \multicolumn{3}{|c|}{$\mathrm{P}$ value } \\
\hline & 0 & 10 & 20 & 30 & & $\mathrm{~L}$ & $\mathrm{Q}$ & C \\
\hline $\mathrm{VF}^{1}$ & 21.7283 & 24.6150 & 26.8983 & 28.4767 & 0.6069 & $<0.0001$ & 0.3125 & 0.971 \\
\hline $\mathrm{C}^{2}$ & 0.0221 & 0.0205 & 0.0220 & 0.0225 & 0.0013 & 0.6731 & 0.4269 & 0.5148 \\
\hline $\mathrm{L}^{3}$ & 12.0383 & 7.1283 & 6.0217 & 4.2250 & 0.0842 & 0.0001 & 0.0889 & 0.2468 \\
\hline
\end{tabular}

${ }^{1} \mathrm{~mL}$ of gas produced per 100 of dry matter, ${ }^{2}$ digestion rate in $\mathrm{h}^{-1},{ }^{3}$ lag time in hours. ${ }^{1} \hat{\mathrm{Y}}=22.04917+0.22542 * * \mathrm{X}\left(\mathrm{R}^{2}=0,8711\right) ;{ }^{3} \hat{\mathrm{Y}}=11.03100-0.24507 * * \mathrm{X}\left(\mathrm{R}^{2}=0,7559\right)$. $\mathrm{SEM}=$ Standard error of the mean; $\mathrm{L}=$ Linear; $\mathrm{Q}=$ Quadratic; $\mathrm{C}=$ Cubic.

For lag time and gas final volume, a linear effect of starch level inclusion was verified, where an increase in starch inclusion promoted a linear increase in gas production, whereas the lag time was reduced. Each 1\% of added starch promoted a linear increase in total gas production of 0.2254 $\mathrm{ml}$ and a decrease in lag time of $0.2451 \mathrm{~h}$. Higher gas production occurred with greater nutrient availability (NFC) for rumen microorganisms in vitro (WASCHECK et al., 2010) as the added starch replaced the forage, which has a high NDF. Similar results were found by Sá et al. (2011), where the higher NFC amount of marandu palisadegrass promoted higher in vitro gas production. 
According to Mertens (1997), the NFC have rapid and complete digestion in the gastrointestinal tract (GIT), while the fiber carbohydrates (FC) have slow and incomplete digestion. Thus, when feeds rich in NFC are added to ruminant diets, an increase in digestibility is expected, as evidenced by the increase in gas final volume.

The effect of NFC addition on the forage DM degradation profile can be variable, since the fermentation of these compounds by microbes present in the inoculum occurs faster and generates different fermentation end-products (BEUVINK; SPOESLTRA, 1992).

Cabral et al. (2002) evaluated maize silage with increasing levels of corn ear, and noted that grain addition, which may lead to an increase in NFC and decrease in FC, can affect estimated kinetic parameters by in vitro systems (batch cultures), specially the accumulation of metabolites (organic acids) at high rates in the incubation environment, or even the exhaustion of other nutrients can inhibit the fermentative action, although there are potentially digestible nutrients.

For the gas production technique, the molar ratio of produced volatile fatty acids (VFAs) can also affect the rate at which gases are produced, in response to available carbohydrate addition, because acetic fermentation has a different effect on gas production than propionate fermentation (BEUVINK; SPOESLTRA, 1992).

The decrease in lag time with starch inclusion reflects the effect of faster starch digestion compared to fiber, which is the main component of forage. Assuming starch has an average digestion rate of $0.20 \mathrm{~h}^{-1}$, in about five hours after the start of incubation, virtually all potentially digestible starch would have been degraded by rumen microflora, thereby affecting the initial time reading of gases and, therefore, the lag time.

Lag time has been described as the time elapsed after sample inoculation so that the digestion process begins, in fact, where events associated to sample hydration, attachment of ruminal microbes to the substrate and removal of compounds resistant to digestion that occur in the incubation environment (MERTENS, 2005). High lag times tend to be observed when the in vitro gas production technique is used for samples with high NDF content, high lignification degree and low NFC content.

Glucose levels caused a quadratic effect on forage digestion rate (C) and lag time (Table 3), with an estimated minimum value for digestion rate of $0.01689 \mathrm{~h}^{-1}$ at a glucose level of $10.07 \%$ and an estimated minimum lag time of $-1.13 \mathrm{~h}$ (zero lag time) at a glucose level of $21.34 \%$.

Table 3. Gas final volume (VF), dry matter digestion rate (C) and lag time (L) when glucose was used to replace forage using the one-pool model of Schofield et al. (1994).

\begin{tabular}{|c|c|c|c|c|c|c|c|c|}
\hline \multirow{2}{*}{ Parameters } & \multicolumn{4}{|c|}{ Glucose levels } & \multirow{2}{*}{ SEM } & \multicolumn{3}{|c|}{ P value } \\
\hline & 0 & 10 & 20 & 30 & & $\mathrm{~L}$ & $\mathrm{Q}$ & $\mathrm{C}$ \\
\hline $\mathrm{VF}^{1}$ & 22.9317 & 23.03 & 24.91 & 23.165 & 0.7605 & 0.4693 & 0.2593 & 0.1499 \\
\hline $\mathrm{C}^{2}$ & 0.0215 & 0.0175 & 0.0208 & 0.0371 & 0.0014 & $<0.0001$ & $<0.0001$ & 0.3809 \\
\hline $\mathrm{L}^{3}$ & 8.32 & 0.3407 & 0.0015 & 0.0015 & 1.137 & 0.0011 & 0.008 & 0.189 \\
\hline
\end{tabular}

${ }^{1} \mathrm{~mL}$ of gas produced per $100 \mathrm{mg}$ of dry matter; ${ }^{2}$ digestion rate in $\mathrm{h}^{-1} ;{ }^{3}$ lag time in hours.

${ }^{2} \hat{Y}=0.0218-0.0010 X+0.000051 \mathrm{X}^{2}\left(\mathrm{R}^{2}=0.93\right) ;{ }^{3} \hat{\mathrm{Y}}=7.95-0.8514 \mathrm{X}+0.0199 \mathrm{X}^{2}\left(\mathrm{R}^{2}=0.7864\right)$.

$\mathrm{SEM}=$ Standard error of the mean; $\mathrm{L}=$ Linear; $\mathrm{Q}=$ Quadratic; $\mathrm{C}=$ Cubic. 
Total gas volume was not affected by the added glucose levels, which was different from that observed for starch inclusion. However, this behavior may be due to the use of the one-pool model (SCHOFIELD et al., 1994), which did not properly fit the gas production profiles observed, especially for higher glucose levels. Thus, the inadequacy of the one-pool model to estimate the kinetic parameters contributed to the absence of glucose level effects on the gas VF, as can be seen in Figure 1.

Figure 1. Gas production profile for observed (open circles) and model-predicted (solid line) data by the one-pool model for added glucose levels of zero (a), 10 (b), 20 (c) and 30\% (d) to the incubation flasks.

(a)

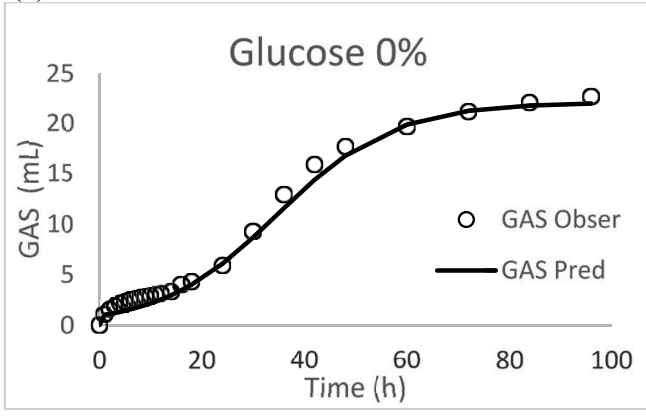

(c)

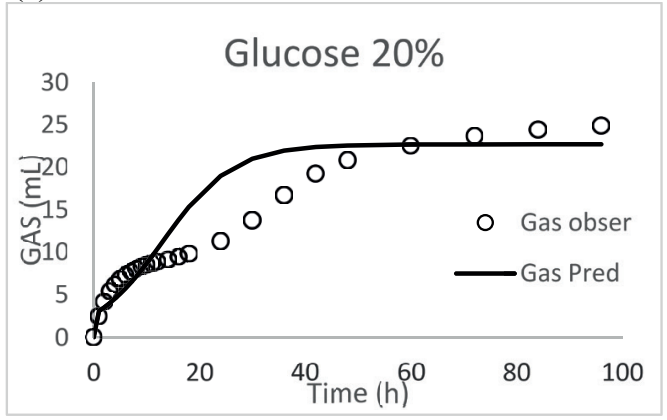

(b)

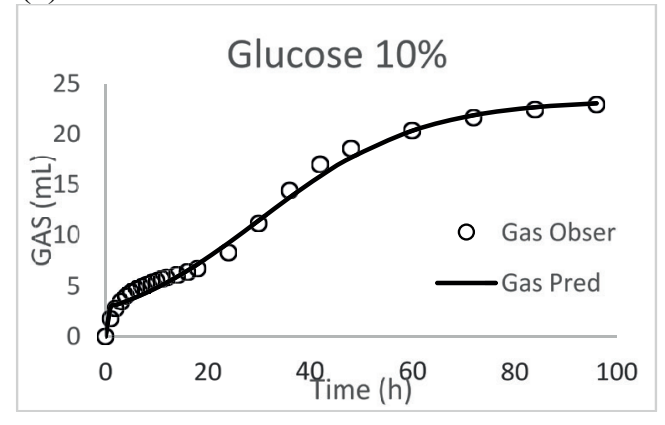

(d)

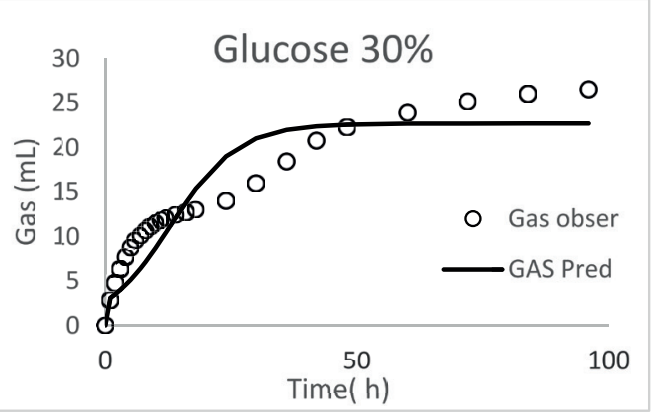

The graphs in Figure 1 demonstrate that glucose addition promoted a change in gas production profiles, especially when comparing glucose levels of 20 and $30 \%$ with others, featuring what is called diauxie (BROCK et al., 2008). Diauxie has been described as the occurrence of two microbial growth curves on the same gas production profile. This phenomenon occurs due to the presence of two substrates with different preferences by ruminal microbes or the presence of polymeric and soluble nutrients with different digestion rates.

Considering the above, the two-pools model (SCHOFIELD et al., 1994) was chosen to estimate the in vitro gas production kinetic parameters when glucose was used, and an improvement in fit was observed compared to the one-pool model as shown in Table 4 and Figure 2. Although the data listed in Table 4 were not statistically analyzed, since the two-pools model fit only to the gas production profiles of higher glucose levels (20 and 30\%), a numerical increase in gas final volume (total Vf) is perceived with an increase in glucose levels, unlike that shown in Table 3 (onepool model).

Failure to observe an increase in DM digestion rate by starch addition could be because it was 
masked by the negative effects of adding starch on or by the mathematical models used, since gases forage DM digestion. This would not be possible from both components would be generated to detect by the gas production monitoring system simultaneously throughout incubation.

Table 4. Kinetic parameters of forage digestion according to glucose inclusion levels using the two-pools model of Schofield et al. (1994).

\begin{tabular}{lcccc}
\hline \multirow{2}{*}{ Parameters } & \multicolumn{4}{c}{ Glucose levels \% } \\
\cline { 2 - 5 } & 0 & 10 & 20 & 30 \\
\hline $\mathrm{VF}^{1}$ & -- & -- & 0.03 & 7.46 \\
$\mathrm{C}^{2}$ & -- & -- & 0.4656 & 0.2531 \\
$\mathrm{~L}^{3}$ & 8.32 & 0.32 & 1.54 & 1.27 \\
$\mathrm{VF}^{1}$ & 22.93 & 23.03 & 20.96 & 19.13 \\
$\mathrm{C} 2^{2}$ & 0.0215 & 0.0175 & 0.0175 & 0.0167 \\
$\mathrm{VF}^{2}$ total & & 23.03 & 25.00 & 26.59 \\
\hline $\mathrm{R}^{2}$ & 22.93 & 0.98 & 0.99 & 0.99 \\
\hline
\end{tabular}

${ }^{1} \mathrm{~mL}$ of gas produced per $100 \mathrm{mg}$ of dry matter. ${ }^{2}$ digestion rate in $\mathrm{h}^{-1} .{ }^{3}$ lag time in hours; $\mathrm{R}^{2}$ values obtained for model fit to observed data; gas final volume of rapid digestion fraction (VF1); digestion rate of rapid digestion fraction (C1); lag time (L); gas final volume of slow digestion fraction $(\mathrm{VF} 2)$; digestion rate of slow digestion fraction $(\mathrm{C} 2)$; gas total volume $(\mathrm{VF}$ total $=\mathrm{Vf1}+\mathrm{Vf2})$.

Figure 2. Gas production profile for observed (open circles) and model-predicted (solid line) data by the two-pools model for added glucose levels of zero (a), 10 (b), 20 (c) and 30\% (d) to the incubation flasks.

(a)

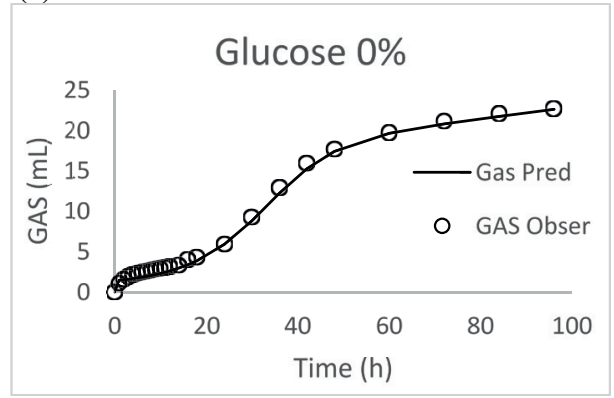

(c)

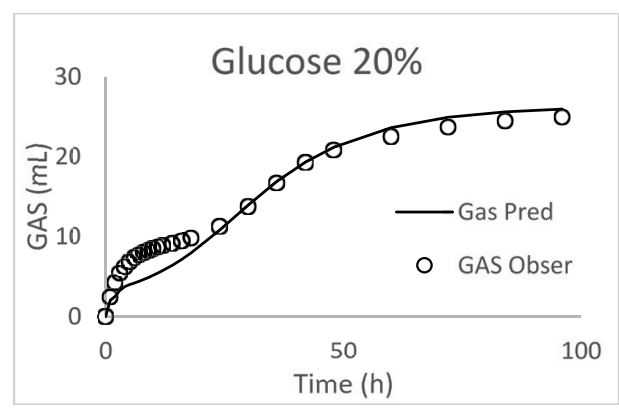

(b)

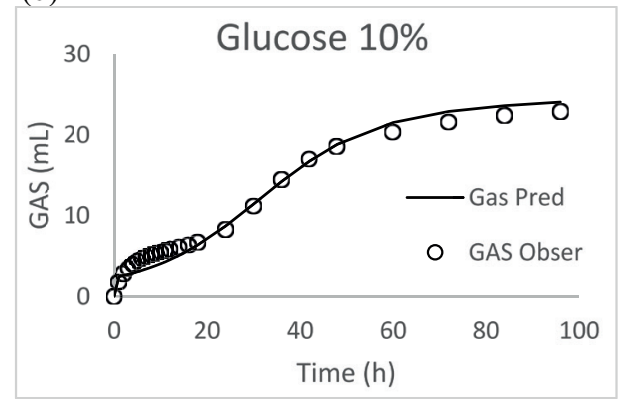

(d)

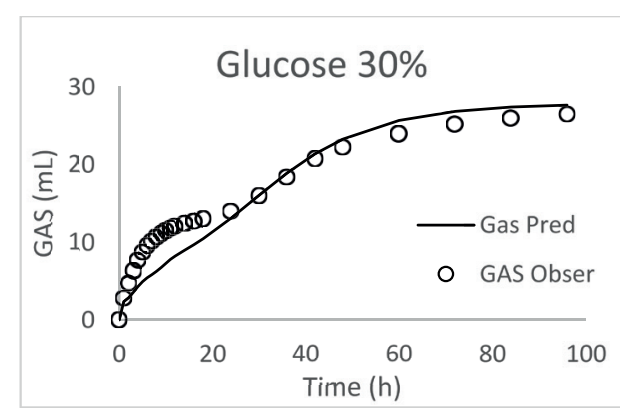


Thus, to assess the effect of starch or glucose levels on NDF digestion, considering the limitations of the in vitro gas production technique, NDF disappearance was evaluated at three incubation times: 24, 48 and $96 \mathrm{~h}$.

For NDF digestion using starch, there was a linear reduction in NDF digestion of $0.296 \%$ at $24 \mathrm{~h}$ after inoculation, however, no effect was observed at 48 or $96 \mathrm{~h}$ (Table 5). Inhibition of NDF digestion at $24 \mathrm{~h}$ may have been caused by the effect of starch on the growth of microorganisms that digest it, which probably competed for essential nutrients for metabolism with cellulolytic organisms (RUSSELL, 2002). At the same time, the increased availability of soluble carbohydrates (glucose, maltose) resulting from starch digestion can enhance their direct use by cellulolytic organisms, and therefore have some negative effect on the synthesis of enzymes related to cellulose digestion. This mechanism has been observed in various microorganisms, where the presence of the final product of the metabolic pathway or the nutrients in the culture medium inhibits the gene expression associated with digestion of a complex polymer or its synthesis by the organism.

Table 5. Least squares means, standard error of the mean (SEM) and $\mathrm{P}$ value for NDF in vitro digestion at incubation times of 24 (Dig24), 48 (Dig48) and 96 (Dig96) hours according to starch inclusion levels.

\begin{tabular}{|c|c|c|c|c|c|c|c|c|}
\hline \multirow{2}{*}{ Time } & \multicolumn{4}{|c|}{ Starch levels } & \multirow{2}{*}{ SEM } & \multicolumn{3}{|c|}{ P value } \\
\hline & 0 & 10 & 20 & 30 & & $\mathrm{~L}$ & $\mathrm{Q}$ & $\mathrm{C}$ \\
\hline Dig241 & 16.18 & 12.33 & 10.33 & 6.98 & 3.86 & 0.01 & 0.90 & 0.73 \\
\hline Dig48 & 60.15 & 58.17 & 64.46 & 56.53 & 3.82 & 0.80 & 0.47 & 0.24 \\
\hline Dig96 & 73.53 & 72.55 & 70.63 & 71.79 & 1.92 & 0.13 & 0.28 & 0.36 \\
\hline
\end{tabular}

$\mathrm{L}=$ Linear; $\mathrm{Q}=$ Quadratic; $\mathrm{C}=$ Cubic.

${ }^{1} \hat{Y}=15.90-0.296 X\left(R^{2}=0.2686\right)$.

The increase in concentration of soluble sugars can also inhibit the mechanisms associated with attachment to substrate (BROCK et al., 2008), which are necessary for digestion of insoluble components, especially those from plant cell walls (cellulose, hemicellulose).

Failure to observe a difference in NDF digestion at 48 and $96 \mathrm{~h}$ indicates that there was recovery of cellulolytic activity during incubation, indicating that the starch inhibitory effect was only transitory.

Different from that observed for starch, an increase in glucose concentration in the incubation medium caused a linear decrease in NDF digestion of $0.3269,0.4171$ and $0.2340 \%$, respectively, for times 24, 48 and $96 \mathrm{~h}$ (Table 6). That is, use of high glucose concentrations in culture media causes extended negative effects on NDF digestion.

The probable explanation for the prolonged negative effect of glucose level on NDF digestion compared to the short negative effect of starch is the difference in soluble carbohydrate release between tested energy sources. While starch is digested by the ruminal microflora at a rate of $0.20 \mathrm{~h}^{-1}$, glucose is readily available (SNIFFEN et al., 1992), providing immediate effects on ruminal microbiota and their behavior, including growth rate and gene expression. 
Table 6. Least squares means, standard error of the mean (SEM) and P value for NDF in vitro digestion at incubation times of 24 (Dig24), 48 (Dig48) and 96 (Dig96) hours according to glucose inclusion levels.

\begin{tabular}{|c|c|c|c|c|c|c|c|c|}
\hline \multirow{2}{*}{ Time } & \multicolumn{4}{|c|}{ Glucose levels } & \multirow{2}{*}{ SEM } & \multicolumn{3}{|c|}{$P$ value } \\
\hline & 0 & 10 & 20 & 30 & & L & $\mathrm{Q}$ & $\mathrm{C}$ \\
\hline Dig241 & 19.4552 & 17.9311 & 13.8241 & 12.5509 & 5.3498 & 0.0118 & 0.9301 & 0.3874 \\
\hline Dig48² & 61.9001 & 62.7109 & 59.4953 & 49.0694 & 2.4545 & 0.0090 & 0.0620 & 0.7816 \\
\hline Dig96 $6^{3}$ & 74.0779 & 73.8471 & 72.5404 & 66.7242 & 2.3799 & 0.0473 & 0.2320 & 0.7273 \\
\hline
\end{tabular}

$\mathrm{L}=$ Linear; $\mathrm{Q}=$ Quadratic $\mathrm{C}=$ Cubic.

${ }^{1} \hat{Y}=20.19-0.3269 X\left(R^{2}=0.174\right) ;{ }^{2} \hat{Y}=64.55-0.4171 X\left(R^{2}=0.52\right) ;{ }^{3} \hat{Y}=75.30-0.234 X\left(R^{2}=0.337\right)$.

Considering that there was no effect of added glucose and starch levels on culture medium $\mathrm{pH}$ at different evaluation times, the energy source effects were not associated with $\mathrm{pH}$ change, but with a direct effect on the microbiota.

The effect of incubation time was verified by the culture medium $\mathrm{pH}$ values, which were $6.89,6.72$ and 6.67, respectively, for times 24, 48 and $96 \mathrm{~h}$. The lower $\mathrm{pH}$ values observed in the final incubation times reflect the accumulation of fermentation endproducts (VFA's) over time. Although a decrease in $\mathrm{pH}$ was expected with an increase in starch or glucose levels, this behavior was not observed. However, considering that the maximum glucose and starch levels tested was 30\%, the levels were likely not high enough to promote a more pronounced effect on ruminal $\mathrm{pH}$, despite the use of a batch culture, where there was no entrance of nutrients and no removal of fermentation products (VAN SOEST, 1994).

Negative effects on forage digestion have been associated with a rumen $\mathrm{pH}$ below 6.0 , competition for essential nutrients (nitrogen compounds, vitamins, branched chain fatty acids and minerals) between fibrolytic and non fibrolytic organisms, and a reduction in fibrolytic microorganism attachment and / or a decrease in gene expression or activity of enzymes associated with fiber digestion (RUSSELL, 2002). El-Shazly et al. (1961) found that in mixed ruminal bacteria cultures, and through in situ techniques, the addition of starch resulted in a decrease in purified cellulose digestion by limiting nitrogen to cellulolytic bacteria.

Hitchner and Leatherwood (1980) proposed that the cellulase enzyme is controlled by repression mechanisms, and cellulolytic bacteria are controlled by catabolite repression of cellulolytic enzymes. However, Smith et al. (1973) proposed that the addition of cellobiose inhibits cellulase action rather than its production.

Some authors proposed the negative effect of bacteriocins by amylolytic microorganisms, which would inhibit the activity of fibrolytic enzymes (ARROQUY et al., 2005; PIWONKA; FIRKINS, 1993). This likely occurred at the $24 \mathrm{~h}$ mark, when there was a decrease in NDF digestion with starch inclusion, which was reversed during the incubation.

Considering that gases generated in incubation flasks reflect digestion of the sample or incubated ingredients by ruminal microflora, of which the final product is mostly VFA which are the main energy source for ruminants, it can be inferred that based on the gas final volume, starch addition up to $30 \%$ would promote an increase in dietary energy availability. Therefore, this would lead to an increase in performance of animals kept on well-managed marandu palisadegrass pastures with a similar composition to that used in this study. The effects of glucose addition were not desirable, especially at levels of 20 and $30 \%$, since it caused a decrease in fiber digestion during prolonged incubation times, which may not increase dietary energy availability and animal performance. 
Piwonka and Firkins (1993) demonstrated that adding glucose at the beginning of a $72 \mathrm{~h}$ fermentation period reduced the NDF digestion rate and the carboxymethylcellulase activity, even with maintenance of the culture $\mathrm{pH}$ above 6.2. However, adding glucose after $24 \mathrm{~h}$ of incubation, which is assumed to be the time to maximum microbial colonization, did not decrease NDF digestion rate, but did decrease carboxymethylcellulase activity.

An increased concentration of soluble sugars in the medium provides readily fermentable carbohydrates to ruminal bacterial cells, supplies the energy requirement of these microorganisms and, thus, reduces the attachment of bacteria to the feed particles (FARENZENA et al., 2014).

\section{Conclusion}

Glucose supplementation promotes different effects from starch supplementation on the in vitro gas production kinetic parameters of marandu palisadegrass, highlighting the prolonged negative effect on NDF digestion.

\section{References}

ARROQUY, J. I.; COCHRAN, R. C.; NAGARAJA, T. G.; TITGEMEYER, C. E.; JOHNSON, D. E. Effect of types of non-fiber carbohydrates on in vitro forage fiber digestion of low-quality grass hay. Animal Feed Science and Technology, Amsterdam, v. 120, n. 1, p. 93-106, 2005.

BEUVINK, J. M. W.; SPOELSTRA, S. F. Interactions between substrate, fermentation end-products, buffering systems and gas production upon fermentation of different carbohydrates by mixed rumen microorganisms in vitro. Applied Microbiology and Technology, Netherlands, v. 37, n. 4, p. 505-509, 1992.

BROCK, T. D.; MADIGAN, M. T.; MARTINKO, J. M. Biology of microorganisms. $7^{\text {th }}$ ed. Englewood Cliffs: Prentice Hall International, 2008. 1061 p.

CABRAL, L. S.; VALADARES FILHO, S. C.; DETMANN, E.; ZERVOUDAKIS, J. T.; PEREIRA,
O. G.; VELOSO, R. G.; PEREIRA, E. S. Cinética ruminal das frações de carboidratos, produção de gás, digestibilidade in vitro da matéria seca e NDT estimado da silagem de milho com diferentes proporções de grãos. Revista Brasileira Zootecnia, Viçosa, MG, v. 31, n. 6, p. 2332-2339, 2002.

COSTA, V. A. C.; DETMANN, E.; VALADARES FILHO, S. C.; PAULINO, M. F.; HENRIQUES, L. T.; MANTOVANI, H. C. Degradação in vitro da fibra em detergente neutro de forragem tropical de alta qualidade em função da suplementação com proteína e/ou carboidratos. Revista Brasileira de Zootecnia, Viçosa, MG, v. 38, n. 9, p. 1803-1811, 2009.

DETMANN, E.; QUEIROZ, A. C.; ZORZI, K.; MANTOVANI, H. C.; BAYÃO, G. F. V.; GOMES, M. P. C. Degradação in vitro da fibra em detergente neutro de forragem tropical de baixa qualidade em função da suplementação com proteína verdadeira e/ou nitrogênio não-proteico. Revista Brasileira de Zootecnia, Viçosa, MG, v. 40, n. 6, p. 1272-1279, 2011.

DETMANN, E.; SOUZA, M. A.; VALADARES FILHO, S. C.; QUEIROZ, A. C.; BERCHIELLI, T. T.; SALIBA, E. O. S.; CABRAL, L. S.; PINA, D. S.; LADEIRA, M. M.; AZEVEDO, J. A. G. Métodos para análise de alimentos. Instituto Nacional de Ciência e Tecnologia de Ciência Animal. Visconde do Rio Branco: Suprema, 2012. 214 p.

EL-SHAZLY, K.; DEHORITY, B. A.; JOHNSON, R. R. Effect of starch on the digestion of cellulose in vitro and in vivo by rumen microorganisms. Journal of Animal Science, Champaign, v. 20, n. 1, p. 268-273, 1961.

FARENZENA, R.; KOZLOSKI, G. V.; MEZZOMO, M. P.; FLUCK, A. C. Forage degradability, rumen bacterial adherence and fibrolytic enzyme activity in vitro: effect of $\mathrm{pH}$ or glucose concentration. Journal of Agricultural Science, Cambridge, v. 152, n. 2, p. 325-332, 2014.

GRANT, R. J.; MERTENS, D. R. Influence of buffer $\mathrm{pH}$ and raw corn starch addition on in vitro fibre digestion kinetics. Journal of Dairy Science, Madison, v. 75, n. 10, p. 2762- 2768, oct. 1992.

HADDAD, S. G.; GRANT, R. J. Influence of nonfibre carbohydrate concentration on forage fibre digestion in vitro. Animal Feed Science and Technology, Amsterdam, v. 86 , n. 1-2, p. 107-115, july 2000.

HITCHNER, E. V.; LEATHERWOOD, J. M. Use of a cellulase-derepressed mutant of Cellulomonas in the production of a single-cell protein product from cellulose. Applied and Environmental Microbiology, Washington, v. 39, n. 2, p. 382-386, 1980. 
KRAUSE, D. O.; DENMAN, S. E.; MACKIE, R. I.; MORRISON, M.; RAE, A. L.; ATTWOOD, G. T.; MCSWEENEY, C. S. Opportunities to improve fiber degradation in the rumen: microbiology, ecology, and genomics. FEMS Microbiology Reviews, Oxford, v. 27, n. 5, p. 663-693, 2003.

McDOUGALL, E. I. Studies on ruminant saliva. 1. The composition and output of sheep's saliva. Biochemical Journal, London, v. 43, n. 1, p. 99-109, 1948.

MERTENS, D. R. Creating a system for meeting the fiber requirements of dairy cows. Journal of Dairy Science, Madison, v. 80, n. 7, p. 1463-1481, 1997.

MERTENS, D. R. Rate and extent of digestion. In: DIJKSTRA, J.; FORBES, J. M.; FRANCE, J. (Ed.). Quantitative aspects of ruminant digestion and metabolism. $2^{\text {th }}$ ed. Cambridge: CABI Publishing, 2005. p. 13-48.

MERTENS, D. R.; LOFTEN, J. R. The effect of starch on forage fiber digestion kinetics in vitro. Journal of Dairy Science, Madison, v. 63, n. 9, p. 1437-1446, 1980.

PAULINO, M. F.; DETMANN, E.; VALADARES FILHO. S. C. Suplementação animal em pasto: energética ou proteica? In: SIMPÓSIO SOBRE MANEJO ESTRATÉGICO DA PASTAGEM, 3., Viçosa, MG. Anais... Viçosa, MG: SIMFOR, 2006. p. 359-392.

PELL, A. N.; SCHOFIELD, P. Computerized monitoring of gas production to measure forage digestion in vitro. Journal of Dairy Science, Madison, v. 76, n. 9, p. 10631073, 1993.

PIWONKA, E. J.; FIRKINS, J. L. Effect of glucose fermentation onfiber digestion by ruminal microorganisms in vitro. Journal of Dairy Science, Madison, v. 79, n. 12, p. 2196-2206, 1993.
RUSSELL, J. B. Rumen microbiology and its role in ruminant nutrition. Ithaca: James B. Russell, 2002. 119 p.

SÁ, J. F.; PEDREIRA, M. S.; SILVA, F. F.; FIGUEIREDO, M. P.; REBOUÇAS, G. M. N.; SOUZA, D. R. Cinética da fermentação in vitro do capim-Marandu em diferentes idades de corte. Acta Scientiarum, Maringá, v. 33, n. 3, p. 225-231, 2011.

SCHOFIELD, P.; PITT, R. E.; PELL, A. N. Kinetics of fiber digestion from in vitro gas production. Journal of Animal Science, Champaign, v. 72, n. 11, p. 2980-2991, 1994.

SMITH, W. R.; YU, I.: HUNGATE, R. E. Factors affecting cellulolysis by Ruminococcus albus. Journal Bacteriology, Washington, v. 114, n. 2, p. 729-737, 1973.

SNIFFEN, C. J.; O'CONNOR, D. J.; VAN SOEST, P. J.; FOX, D. G.; RUSSELL, J. B. A net carbohydrate and protein system for evaluating cattle diets: carbohydrate and protein availability. Journal of Animal Science, Champaign, v. 70, n. 11, p. 3562-3577, 1992.

UDÉN, P.; ROBINSON, P. H.; MATEOS, G. G.; BLANK, R. Use of replicates in statistical analyses in papers submitted for publication in animal feed science and technology. Animal Feed Science and Technology, Amsterdam, v. 171, n. 1, p. 11-15, 2012.

VAN SOEST, P. J. Nutritional ecology of the ruminant. $2^{\text {th }}$ ed. New York: Cornell University Press, 1994. 476 p.

WASCHECK, R. C.; REZENDE, P. L. P.; MOREIRA, P. C.; REIS, R. B.; ROSA, S. R. A.; MENDONÇA, A. C. Degradabilidade e produção de gases in vitro de fontes energéticas alternativas na alimentação de ruminantes. Acta Scientiarum, Maringá, v. 32, n. 4, p. 425-430, 2010. 